\title{
Prelude to a Grid
}

\section{Energy, Gender and Labour on an Electric Frontier}

\author{
Kristin D. Phillips
}

\begin{abstract}
People in the Singida region of Tanzania have long utilized diverse energy sources for subsistence. The wind separates grain from chaff. The sun ripens the millet and dries it for storage. More recently, solar panels charge phones and rural electricity investments extend the national grid. Yet as an electric frontier, Singida remains only peripherally and selectively served by energy infrastructures and fossil fuels. This article sketches Singidans' prospect from this space and time of energy transition. Drawing on ethnographic research conducted between 2004 and 2019, it asks: how do rural Singidans eke energy from their natural and social environment? How can ideas of the sun and of labour in Nyaturu cosmology inform understandings of energy? And how are new energy technologies reshaping Singida's social and economic landscape? I theorize energy as a deeply relational and gendered configuration of people, nature, labour and sociality that makes and sustains human and natural life.
\end{abstract}

Keywords: Africa, electricity, energy, gender, labour, nature, solar, Tanzania

Nyaturu-speakers in the central Tanzanian district of rural Singida have long tapped into a range of energy systems to make life happen. Firewood and charcoal from surrounding forests fuel cooking. The eastern Singida winds separate grain from chaff. The sun ripens the millet and maize and dries it for storage. More recently, kerosene fuels lamps, and rural electricity enclaves connect to the national grid to light up schools, businesses and clinics. Such connections are still rather sparse: as of 2017 (and depending on which statistics you consult), only between 17 and 24 per cent of rural Tanzanians have household access to electricity. Instead, rural Tanzanians continue to eke energy from their natural and social environment and from their own proverbial elbow grease, and they consume it sparingly. The precarity of food production and subsistence in Singida certainly propels this energy thrift.

Yet this landscape is also changing. By 2017, Singidans' purchase and use of small solar panels and appliances - lights, radio, television and cell phone chargers - had 
exploded in Singida, as it had elsewhere in sub-Saharan Africa. Mainland Tanzanian President John Magufuli's drive to develop regional manufacturing plants has incentivized rural electrification schemes that - after five decades of government promises - are finally hitching roadside villages to the national grid. Tanzania's first large-scale wind farm was contracted for construction in eastern Singida.

Based on ethnographic research conducted in rural Singida since 2004, this article engages recent work in the anthropology of energy to sketch Singidans' prospect from this time and space of energy transition and change. It contributes to the ethnographic theorization of energy among people and places that formal energy infrastructures reach only peripherally or tangentially (cf. Cross 2013). Social and economic life on this electric frontier - it is important to note - is inflected with a Nyaturu cosmology that sees the sun, moon and Pleiades (the Seven Sisters constellation) as the drivers of a recurrent cycle of life, food production and social order (Phillips 2018). Although Singida has long borne the imprints and effects of the carbon world, its propensity to conquer and rule, its aspirations and its climate implications, it has until just recently remained on the carbon periphery, betwixt and between national infrastructures. Its dry climate and lack of infrastructure, education and fossil fuels rendered it an object of relative indifference and apathy to both colonial and postcolonial states. As primarily a labour reserve for at first British colonialism, and later the national economy, the region was linked to projects of carbon capitalism mainly by colonial regard for its cheap human capital and abundant land.

It is this conjunction of energy infrastructures, embodied labour and social practice that I explore in this article. First, I briefly offer a state-level perspective on energy in Tanzania in order to provide a sense of the national energy structures and imaginations that encroach upon, but do not determine, energy practice and perception in Singida. Then, responding to calls to bring situated knowledge, cultural practice, materiality and political economy to the study of energy and electrification (Winther and Wilhite 2015: 574; cf. Adunbi 2015; Boyer 2015; Degani 2017; Groves et al. 2017; Gupta 2015; Strauss et al. 2013), I ask: how do rural Singidans patchwork power sources together in this dynamic energy context, cajoling energy from their natural and social environments? How can notions of the sun and of labour in Nyaturu cosmology inform our contemporary theorizations of energy? And how is the 'economy of interdependent flows' in Singida being 'inflected, redistributed, or otherwise rearranged' (Degani, Chalfin and Cross, this volume) in the face of new solar energy infrastructures and selective grid investments? By looking beyond just the 'energy that counts' (i.e. fossil fuels and grid electricity) in industry and policy narratives, I theorize energy as a deeply relational and gendered configuration of people, nature, labour and social practice that makes and sustains (if sometimes barely) human and natural life. 


\section{Energy in the era of Magufuli}

In 2015, John Pombe Magufuli was inaugurated as Tanzania’s fifth president. Much of Magufuli's economic platform is centred on regional development of manufacturing and agricultural processing plants, bringing concerns about energy and electricity directly to the fore of government planning. The rural energy sector in Tanzania, like much of the urban sector, has historically been dominated by biomass fuels like charcoal and firewood (which constitute 90 per cent of the primary energy supply). Electricity, introduced selectively in the British colony of Tanganyika in 1908, remained until about ten years ago restricted to a national grid that reached less than a fifth of the population. With the national grid's limited 1600 MW capacity and its primary reliance on seasonally variable hydropower and - to a lesser extent - petroleum (Makoye 2015), Tanzanian electricity policies have been relatively unambitious until only recently, keeping a primary focus on increased reliability for industry, business and already-connected households (URT 2003, 2005, 2008, 2017).

In the last ten years, however, the Tanzanian government has increasingly prioritized the relationship between the country's domestic energy supply, economic and social development, and the extension of national and regional electricity grids. A diversification in Tanzania's energy portfolio through the 2010 discovery of significant offshore natural gas reserves in southern Tanzania provided some initial impetus for the government to address the lack of electricity services. The gas reserves are widely perceived to be a windfall for the government (though wresting profits from multinational companies has proven to be no easy feat). And plans that Tanzania will soon be a net exporter of electricity to its neighbours, while twothirds of households in Tanzania (and only a tenth in rural areas) have no access, have not sat well with people. Not surprisingly, energy concerns (and increasingly rural energy concerns) now reside at the heart of current government preoccupations (Matfess 2013), discourses of political legitimacy (Kilyinga and Saiboko 2013; Phillips 2013, 2014) and popular mobilizations (Balile 2013; Simba 2012).

The Tanzanian government's goals along these lines are both specific and ambitious. Policy makers aim to make Tanzania a middle-income country by 2025 , which means that GDP per capita must be increased from USD 640 to USD 3000. To achieve such quick economic growth, the government has set its sights on increasing electricity generation to $10,000 \mathrm{MW}$, electricity connection levels from 24 per cent in 2014 to 50 per cent by 2025, and access levels from 36 per cent to 75 per cent over the same time span. Tanzania mainland's Rural Energy Agency (REA), established in 2007, has been tasked with implementing the extension of the grid into rural areas. Through aggressive support of REA during his tenure as Minister of Energy and Minerals (2012 to 2016), Sospeter Muhongo became known as Waziri wa Nguzo, 'the Minister of Power Poles'. His leadership saw the installation of power columns and electrical wiring throughout many rural areas and a broad expansion of villages' access to the grid, even if household connection rates remain low. Rural Tanzanians in places like Singida hold out hope that grid connections 
will not only augment their access to household amenities like refrigeration and lighting, but also that it will boost their opportunities for employment.

For many poor households and geographically inaccessible villages, renewable energy (mainly solar, but also hydro- and biogas) has offered an important alternative, or at least a temporary stopgap, to grid exclusions (Kassenga 2008; Ondraczek 2013). Since 2013, Tanzania has seen significant increase in the use and distribution of solar systems, with approximately 24.7 per cent of electrified houses using solar power (URT 2017). Solar investment companies have introduced pay-as-you-go business models, enabling people to pay for solar energy with lower upfront costs (ADB 2015; Economist 2016). Solar technology projects in Tanzania range from solar lantern distribution to schoolchildren, to household systems, to mini-grids that power multiple homes. But the government's interest in renewable energy investment seems to wax and wane directly in relation to cycles of optimism and disillusionment with centralized grid power. Frequent drought-related power outages between 2014 and 2017 saw a boom in solar investment, while recent plans for a mega-hydro project in the Rufiji basin (that should add $2100 \mathrm{MW}$ to the existing $1600 \mathrm{MW}$ capacity) have seen that solar investment and interest collapse. As a number of interlocutors noted, 'President Magufuli likes big things', and solar is seen to be too small and too piecemeal to keep the government's attention for long. But government investment or not, solar technologies have increasingly become standard fare in rural Singidans' repertoire of energy possibilities.

\section{Theorizing energy, sociality and labour in Singida}

Doing credit to the experience and practice of energy in Singida, I will show, requires both a different scope and a different register to the political frameworks reviewed above. Conventional policy and popular narratives about energy tend to hold up human beings as rational and individual actors whose expertise and skill - with the aid of technology, proper funding and fertile political environments - exploit the earth's physical properties to pursue their own ends and interests. In this view, variation in energy access is attributed to some people being more adept, or more endowed with resources, or more historically or geographically well-positioned to access and enjoy the fruits of such exploitation. Others, in this narrative, remain in the not-yet of energy poverty.

There are three main conceptual issues with this conventional energy narrative. First, it maintains a binary between people and nature, as if people were separate or could ever exist independently from the natural world. Indeed, human beings have since the earliest days been mixed and mingled with the earth in what Raymond Williams called a 'relational configuration' (1980: 83). One of the most dynamic areas of energy scholarship has been the work of those theorists who dwell in the conceptual grey space between nature and society - between the materiality of natural resources and the human beings that instrumentalize and metabolize them (Fischer-Kowalski 2002; Latour 1993; Mitchell 2011; Moore 2015). A recent return to Marx's notion of the metabolic rift (Foster 1999; Kawa et al. 2019; Moore 2017; 
Schneider and McMichael 2010), for example, has scholars highlighting the role that humans have long played in producing the physical environment that sustains them. Such scholarship highlights the interdependency, even the co-constitution of people and nature. Nutrients have long been cycled between people and the land, with nutrients extracted through agriculture, metabolized as fuel or food by humans and animals into waste, and deposited back into the land for further cultivation or continued support of wild animal and plant species. The 'rift' argument holds that with the migration of people to cities and subsequent geographical separation of rural food production and urban food consumption, a metabolic rift was born, in which rural land is widely and repeatedly stripped of vital nutrients, and cities become polluted. A key conceptual contribution of this literature relevant to this article has been the premium it places on energy as a relational configuration, and of the human body as intermediary - even technology - of energy production.

Secondly, the conventional energy narrative misses the important ways in which the material world acts on and produces people and their social, political and economic organization. Building on developments in actor-network theory (Latour 2005), scholars of energy have raised critical questions about how the material properties of particular energy sources predispose the adoption of certain kinds of technical arrangements and political, economic and social relations (Appel 2012; Howe 2014; Mitchell 2011; Watts 2005). Thus, they point out that the objects, systems and substances in our lives do not just reflect our social priorities, our ingenuity, our hierarchies or practices, but they may also configure (and reconfigure) them (Jensen and Morita 2017; Larkin 2013). Acknowledging this agency of materiality allows us to track and compare change across the introduction of diverse energy resources and infrastructures by focusing our attention on the social, political and economic practices that cohere around new technologies.

Finally, the conventional narrative affirms a modernist teleology of energy that privileges an earth-toxic, fossil-fuel and growth-driven energy regime as 'the energy that counts', and renders both invisible and invaluable the human labour (both agricultural and industrial) that has always been at the heart of subsistence and human flourishing. A June 2013 issue of Scientific American, for example, offered a glimpse of 'Africa's Energy Poverty, As Seen from Space' through a night-time satellite image of the African continent:

Take a look at the image below. What do you see? Can you make out the mark of civilization, the tell-tale glow of lights from cities and villages? Does it look sparser than you expect? It's not because the continent of Africa is devoid of people. It's because the gift of energy services hasn't reached many of the billion-plus residents. It's what is called 'energy poverty', that is, a lack of access to what many consider to be the common element of modern living: electricity. (Wogan 2013)

On one hand, pointing out the energy poverty that characterizes much of Africa offers an important explanation for differences in indicators such as GDP or economic growth between countries in Africa and the Global North. On the other, such a picture paints Africa and Africans as not-yet-in-motion, as a literally Dark 
Continent, as it were, awaiting the fuel to be set in motion. This erases the embodied energy and energy syncretism that drives so much of life in rural parts of the continent, where human muscle power is a dominant energy source.

This modernist teleology also generally obscures the work of domestic energy production and consumption for cooking, cleaning and transportation of goods to market, which tend to be the purview of women. Although domestic energy consumption constitutes the lion's share of total energy use in developing countries in Africa and Asia, women have remained almost invisible on the supply side of energy studies (Parikh 2000: 11). This stark absence of women and the domestic sphere as 'counting' in analyses of energy and electrification, Wendy Annecke notes, 'would have been a talking point if it were not so "normal"' (2009: 289). With few exceptions (Simcock and Mullen 2016; see also the literature on cooking fuel, for example Iessa et al. 2017), anthropological studies of energy infrastructures have largely focused on the policy, technological and industry spaces that are largely gendered male, and include women and the poor mainly as end users of energy produced elsewhere, rather than as producers, technicians, theorists, or themselves embodied sources of household and commercial energy. These critiques point to a clear need to focus on rural domestic spaces and their gendered energy flows. In situating Singidans' perspective from this electric frontier, I therefore focus on the everyday and intimate of energy practices. I attend not simply to people and places that energy infrastructures reach and serve, but also to those which they do not, or where they do so only peripherally or tangentially.

\section{Energy, subsistence and the sun in Singida}

So what is energy in Singida? Rural Singida consists of a network of interconnected villages, roads and cattle paths that radiate out from Singida Town, a municipality of 150,000 people. Those people who do not migrate away from rural villages for education or work mainly farm and herd for a living. The work of everyday life in Singida is that of harnessing the sun, the wind, gravity, electricity and the caloric intake of people and animals to produce or acquire the basic needs of food, water, shelter, security and human connection. Between 2004 and 2019, Singidans generally agreed upon what constituted basic needs: a litre of grain per day per person, cooking oil, lamp and cooking fuel, soap, salt, matches, mill fees, basic agricultural implements and clothing. For those who do not own livestock, basic needs are usually eked from the physical and social environment through agriculture, brewing sorghum beer, selling eggs, hauling water, firewood or charcoal, or performing agricultural day labour. Aside from purchasing these basic necessities, cash is sometimes (and by some more than others) diverted to purchase beer, meat, rice, sugar or soda. 'Development', on the other hand - metal roofing material, school fees and uniforms, cell phones and vouchers, start-up costs for a small business or for solar panels - was mainly accomplished through cultivating cash crops like sunflower and finger millet, salaried government employment, urban migration, the sale of livestock or remittances from urban kin. 
Singidans have long had their own understandings of the energy flows that sustain them through the slog and strenuousness required to obtain basic needs or, in good years, development. Like many other neighbouring groups, they reference the sun as a vital source of power and order. A widely accepted concept of God among diverse western and northeastern Tanganyikan peoples is one that centres on the sun as divine symbol, with the word for 'sun' deriving from the root -uba or -uva (Iliffe 1979). The Nyaturu ritual 'Prayer to the Sun', or Ukuta Yuva, exemplifies this enduring Nyaturu idiom of 'the sun's unpredictable grace' and has codified Nyaturu beliefs in the cosmological and social order since the earliest accounts of Nyaturu custom (Jellicoe 1978; Jellicoe et al. 1967; Olson 2002; Phillips 2018). It offers a glimpse into a shared cosmology that is constructed around the movements of the sun (Yuva), the moon (Mweri-Matunda) and Pleiades (Kiimia, or the Seven Sisters constellation) whose orderly procession framed the universe as made by the Creator (Matunda).

O SUN, Creator, you have opened. You are praised by the cock and by the morning warbler, by the male donkey and the male goat; by the eland in the forest, a wild animal grazing on the leaves of the muntumba tree. Since you went down we have seen no bad omen; we have heard no funeral cry; no one has died. Sun, you have opened well. Now you have thrown white butter of blessing on the mountain and the baobab tree. May we all be cool. ... At midday pause over a homestead with ten houses, spread out your blessing there; to a homestead with only one house also send goodness. Do not burn us; do not be too hot. In the evening return safely those who have gone herding and those traveling in the forests. Take with you to the west the poisonous snakes, rhinoceroses, lions. Take with you all fevers of our people and our herds; take them to your homestead in the west, to the deep chasm of the borassus palm, and bury them there under a flat stone ... Now go to the east with your coolness, carrying the skin bracelet of an infant and the tail of a wildebeest, breathing saliva of blessing. Scatter the chime on all large trees, pools, forests, cattle-paths and millet fields, cleansing them. You who are my grandmother, you who are my grandfather, Creator, our great God, give me goodness. Put the root of a tree across the path to my homestead, that no troublemaker may come. See that no sleeping child is caused to fall into the fire. I have finished with you, Sun. (Jellicoe et al. 1967: 30-31)

Because of its associations with divining and herding, Nyaturu people render the sun masculine (Jellicoe 1978). As these lines of the prayer reveal, the sun's recurrent cycle of energy controls the coming and going of good, evil, birth, health, death, danger and disease. In the morning, when it is understood to be cool and benevolent, the sun ushers in blessings. He is the prototype of the herder, or protector, and of the diviner, whose insight and foresight brings health and prosperity. In the evening, like the diviner's intermediary, the sun shepherds all things evil and dangerous into the night sky.

For many Singidans, the ecological balance required for subsistence has long relied on people's control of the sun's energy by reciting the Ukuta Yuva during three key ritual events: the women's coming-of-age ritual or imaa, the negotiation of bridewealth between two fathers, and the seeking of the services of a diviner. ${ }^{1}$ 
Together these three rituals aimed at managing gender relations and generational change, building relations with and between affines, and tending to the relation between forces seen and unseen, times past and present, and matters earthly and otherworldly. That it was these three occasions that called for the praising of the sun is suggestive of how the sun's energy fuels sociality, the economy and the natural world, and how people and their sociality regulate the sun's energy. Ecological balance relies not just on reverence for the cosmos, but on respect for the gendered, gerontocratic and patron-client orders that organize labour, authority and the distribution of resources. The sun is not just a source of life-sustaining energy; it demands reciprocation, in social form.

This view of the sun, moon, Pleiades and the annual cycle and historical production they control reflects the concept of oikeios, an idea that Jason W. Moore calls 'a way of understanding the creative, generative, and multi-layered relation of species and environment' (2015:4). Oikeios acknowledges that humans both act and are acted upon by all of nature in the process of environment-making. Nature, including human beings, is in this view both the condition or premise of history, as well as history's outcome. McKenzie Wark (2015) elaborates: oikeios is 'a relation of life-making ... a view of the human unified with nature, of human history as co-produced. It comes from "oikeios topos" or favorable place, the relationship between a plant species and where it is found'. In this view, Singida is thus not, or not only, an electric frontier, a natural and social landscape in energy transition; it is a site where nature has long worked through and worked on human sociality and subsistence.

\section{The metabolics of everyday life in three Singida households}

Akhil Gupta has written of the 'partial presence of modern infrastructure' (2015: 564) in the Global South as the temporality of electricity access, the ebbs and flows of electricity caused by predictably unpredictable long- and short-term outages. In rural Tanzania, this 'partial presence' is as much spatial as it is temporal, configured into patchy spots of electrical access - in town, a village here, a village there. The largely unelectrified rural places that lie between these energy islands contrast sharply with electrified places, which Michael Anusas and Tim Ingold have called a 'make-believe world', where 'things work without calling for productive effort on the part of their operators' and the 'massive apparatus of power generation and transmission' (2015: 541) is obscured or fetishized. They are also a far cry from the dark spaces of nothingness and inactivity suggested by night-time satellite images.

In Singida, productive effort is painfully apparent, even if unequally distributed. And in this context of recurrent drought and food crisis, where the work of food production relies on a short rainy season between December and March, the stakes of such labour are also very high. Singida is one of the more food-insecure regions in Tanzania (Phillips 2009), but is not exceptional in the pervasiveness of hunger or in the degree of its seriousness. ${ }^{2} \mathrm{~A}$ brief sketch of the productive efforts of three diverse but interconnected households in rural Singida reveals the energies that 
people eke, recycle, metabolize and repurpose to drive their everyday lives betwixt and between national energy infrastructures.

When I first moved to the eastern Singida village of Langilanga in 2004, I lived with the head teacher of the primary school and his second wife and their three children. ${ }^{3}$ Nyaiddi was in the privileged position of having a salaried husband and the capital to start a weekly brewing business, where she converts grain, firewood and water into beer that she sells or distributes to fuel her family's relationships and well-being. In addition to her own hard work to feed and tend her family, she was able to outsource some, but not all, of the drudgery of rural subsistence and to provide a minimal means of income to the few women who assisted her. Nyaiddi cooks with charcoal, not firewood, except when she is brewing beer. Charcoal burns more cleanly and does not lead to the dry and hacking cough caused by firewood. Every two to three weeks, a neighbour hikes to the forest where it is produced (about five kilometres away) and brings it to Nyaiddi's home. Every two or three days, Nyaiddi sends her maize with an acquaintance to the electric mill in Suna (the next village over). Each day she is brought three to four buckets of water for bathing, cooking, drinking and washing. She uses the soiled water from cleaning to water a banana tree behind her compound.

Nyaiddi's husband, the head teacher, takes a mini-bus to Singida Town at least once per week to collect his salary, check in with the district education office, drink a few bottles of beer in the pub, and occasionally buy imported cloth or household goods. Every few weeks, he purchases a gallon container of kerosene, which Nyaiddi uses to fill the lanterns that light some rooms at night. Nyaiddi farms a plot of land on the school property, and is now and then helped by the schoolchildren to hoe or harvest. Aside from the mill, she has little contact with or use for electricity, though her husband frequents the cafes in Suna village with the other male teachers to drink or to watch football after school. At night, her three boys (later five boys and one girl) huddle in the lantern-light with her in the kitchen to eat, while her husband eats alone and listens to his battery-powered radio in the living room. After the day's work is done, Nyaiddi buries the hot red embers of her cooking fire in a large pot of cool ash, where they will lie dormant until she rouses them in the morning to start a new cooking fire, sparing her the use of kindling or matches.

Nyazakaria is one of the women who stops by most afternoons to chat with and help Nyaiddi. Their arrangement is never explicitly one of employment but it is clear that flows of labour are met with cash now and then. Nyazakaria lives in a 'traditional' Nyaturu homestead - a u-shaped configuration of mud brick houses. Nyazakaria's husband keeps a few cows and goats who graze by day under the watchful eye of her son, and who sleep by night inside the corral of her homestead so that their manure can be collected and spread on the fields. The family farms several acres and if the rains are kind and the sun does not burn too hot, their harvest feeds them for much of the year. Nyazakaria keeps chickens, and sells the eggs to purchase a daily ration of cooking oil and kerosene (purchased in ounces, not gallons) to light her candles for evening work. The collection of firewood is gruelling, requiring long hikes into the forest and a heavy, awkward load upon 
return. Its remote collection offers the opportunity for sexual freedom and experimentation for the young, but also holds the dangers of sexual violence or unwanted pregnancy. These treks have become further and further as the forest recedes, and so firewood has also become a harbinger of ecological crisis to come.

Nyazakaria counts herself lucky in comparison to those women in the village whose husbands have died or run off, leaving them residing among strangers who quickly reclaim land and livestock in the name of patrilineality. One such woman who carried charcoal to Nyaiddi was Nyaasha. Nyaasha hana hata kuku ('does not even own a chicken' - the idiom for the poorest of the poor). Widowed and without land to farm, Nyaasha relies on opportunities for agricultural day labour during the rainy months, picking wild leafy greens to sell for a pittance, or hauling gunnysacks of charcoal twelve kilometres to town to be able to buy a bit of grain for her children.

For energy, Nyaasha depends on the grace of the sun (that it might not burn too hot), the rain (that it might shower down without flooding), the farmers (that they might give her work) and the food she consumes (that it might carry her through the day to feed her children). For Nyaasha, consumption and production, energy source and energy expenditure, are so tightly coupled that they threaten to become indistinguishable. She labours to consume her basic needs, so that she can labour to consume her basic needs, and so on. The sparseness of this energy desert is indeed inscribed into the leanness of her limbs, born into the strength of her spine, worried into the furrow of her brow, wasted into the peachy fuzz of her hair. And in this project of subsistence she and her two boys are perilously on the edge, for she is always behind, ready to run out of gas.

Between 2004 and 2019, all three of these families had first-hand but intermittent experience in electricity enclaves - other villages connected to the national grid starting in the 1990s. For each family, electricity was a place, a destination to which one must travel. Electricity was also a relationship that must be developed, invoked or purchased. And it was for some a pastime, an activity to be planned and eagerly anticipated. The young male primary school teachers I knew in Langilanga vanished each afternoon to Suna to play pool, listen to music and drink a cold soda. The electric mill in Suna drew older daughters and young wives from throughout the four-village ward and beyond, liberating them from the backbreaking work of grinding grain into flour on a stone, and providing them with an opportunity to gather, mingle, gossip and flirt along the way. I myself had relationships that were initiated and deepened in pursuit of access to electricity. I probably would not have been the regular church-goer that I came to be in Singida if not for the seductive weekly promise to recharge my laptop in Suna's mission station while breakfasting with the sisters after mass. Places in Singida have become the places that they are in relation to electricity (or lack thereof). Suna's electricity made people flock to settle or visit there; it made it selected as the site for the ward secondary school and for small business development. Electricity has accomplished what first president 
Julius K. Nyerere's legendary villagization project could not - a re-engineering and re-inscription of the social and economic landscape to condense people and to draw them into a spatial (though partial) project of modernization and industry.

\section{A prelude to a grid: solar developments and the anticipation of electricity}

Over the course of my most recent research visits to Singida - 2014, 2017 and 2019 - Langilanga began to harvest new crops with the grace of the sun: artificial light and electricity to charge cell phones or even radios or televisions. Indeed, by 2019 solar panels were nearly ubiquitous on the corrugated iron roofs of 'modern houses' as well as on those of thatched mud, except in the homes of the poorest of the poor like Nyaasha. Villagers purchased small solar lamps and small panels at the ward's weekly cattle market from traders who brought the materials from Arusha. The more sophisticated systems, like Nyaiddi's, were purchased in Singida Town and wired and serviced by local electricians. Some panels and lamps were faulty: they had only worked for a few months and then no more, or they never worked, or might have worked but were not installed correctly. Some depended on local technicians for advice and assistance, while others were starting to rig up their own solar contraptions. One young man I interviewed had taken wires from an old transistor radio and hooked them up to his cell phone battery and a small solar panel to create a makeshift phone charger.

By 2017, about a quarter of Singidan adults possessed cell phones - usually basic energy-efficient Nokia or Siemens phones easily charged with locally purchased small solar panels. Cell phones enabled the prompting of remittances from urban kin, participation in mobile banking, and easy communication across and beyond the forty square kilometres of the village. In addition to much-improved communication, Nyazakaria's night-time work and her children's night-time study were now illuminated and facilitated by small solar lamps. Nyaiddi's beer business was enhanced by the ability of her clients to charge their phones, or watch football on her solar TV. By 2019, Nyaiddi and her husband had also installed solar lighting with wall switches in some rooms of their house, giving the strong impression of grid connection. While solar minimally enabled some monetized charging stations or other small business ventures that required light, solar charging was also quickly absorbed into existing relationships of exchange and entitlement. But Nyaasha still alienated from land and food production and reliant on day labour - seemed to move further and further from these highly elaborated energy networks; she was rather more alone, working harder, longer, and for less than ever.

Unlike other parts of rural Tanzania, Singida's solar advances remain largely small, unentangled with larger infrastructures, mini-grids or economic investments, and cobbled together at the individual household level. The solar boom in the city of Arusha in northern Tanzania saw fast-paced venture capital racing between 2014 and 2017 to meet the market demand with new innovations, microgrids and bundled service packages (McKibben 2017). Such a boom was nowhere 
to be found in Singida. In the words of two women I interviewed, 'the electricity of the sun is the electricity of self-reliance' (umeme wa jua ni umeme wa kujitegemea). This phrasing of self-reliance is particularly evocative in Tanzania, where the socialist ideology of self-reliance in the 1960s (understood as voluntary efforts in pursuit of national autonomy and development) gave way in the 1980s to neoliberal policies of self-reliance that individualized development and defunded the state and its infrastructures. The self-reliance of solar energy that Singidans describe today is hardly the renewable energy-fuelled disentanglement and autonomy sought by Zanzibaris (Dean 2012; this issue). It is rather self-reliance in the most contemporary Tanzanian sense - of those who pay tribute in abundance and expect very little in return.

For now, Singidans are comparing the incremental benefits of solar power with the anticipated advantages of connection to the national grid by the Tanzania Electric Supply Company, (TANESCO). This connection is not entirely hypothetical: 2017 and 2018 saw the installation of power columns and the extension of electrical wiring along the road from Suna to Langilanga and beyond. As of 2020, the power lines still do not actually transmit any electricity, but they tower prominently along the roadside, heralding the promise of amplified communication and escalating transformation, a potent symbol (even in their impotency) in the run-up to the 2020 presidential and parliamentary elections. This anticipation is marked not only by the looming columns, but also by the light switches and wiring standing powerless but at the ready in the homes of the most well-off.

Rural electrification in Singida will connect relatively few households to the grid, though it will connect the primary school, the clinic and a few businesses. With limited connections, access to electricity will remain a social affair - enmeshed in historical and new relations of reciprocity, commodification, affiliation or patronage. But Singidans generally agreed that connection to the grid would be exciting. They anticipated that electricity will enhance opportunities for small businesses, employment and access to local services. People imagined opening hair salons, small sewing shops with electric sewing machines, refrigerators for small juice shops, and welding or other improved construction services. They hoped that the regional manufacturing or agricultural processing plants that Magufuli imagined might open up jobs and vocational education. Electricity would certainly enable a wider range of services and goods to be procured locally, rather than in town. Moreover, health clinics and veterinary services would be more accessible with the ability to refrigerate vaccinations. Finally, many said that electricity 'brings the young men back home', when that which can be found in the city can now be found in the village. Some people say there is also a mwamko fulani, a 'certain kind of waking up' that occurs with electrical access that accelerates initiative, opens minds and fosters development. All agreed that connection signalled national inclusion. 


\section{Conclusion}

As a setting of hyper-conservation, Singida provides a rather sharp contrast with Anusas and Ingold's 'make-believe' electrified worlds, where things work without apparent effort. In Singida, productive effort is painfully apparent and readily witnessed, even if unequally distributed and not fully compensated. Energy capture, in the words of the Introduction to this special issue, is an economy of interdependent flows [that is] inflected, redistributed or otherwise rearranged' (Degani, Chalfin and Cross, this volume). What the Singida case highlights is both the emplacement and empeoplement of energy capture, with some individuals being far more emplaced and empeopled than others. Energy is rooted deeply in the capacity to engage in relationships with people, technologies and the landscape towards life-sustaining and life-enhancing ends.

This ethnographic account brings a source of energy into the picture - that produced by the metabolism of the human body - that is not often acknowledged or valued as a productive form of energy. Ultimately, it falls on the backs of men and (especially) women like Nyaasha to produce and transport daily essentials - fuel, food, water and people - when electricity, automated technologies and fossil fuels are physically or economically out of reach. Indeed, energy practices in Singida render some particular bodies as the infrastructure for others; that is, in Brian Larkin's words, as the 'things that create the grounds on which other things operate' (2013: 329). It highlights the metabolism of the human body as a final frontier of energy capture for those who possess little else to fuel daily life, subsistence and desire. Nyaasha labours to consume her basic needs so that she can labour to consume her basic needs, so that she can labour to consume her basic needs. The tightness of this energy loop ensnares Nyaasha almost completely. In the same way as colonial Singidans fuelled the development of Tanganyika through their labour, so men and women like Nyaasha continue to fuel daily life in Singida, particularly when they lack the relations to people and the landscape that they need to access or produce other types of value. The invisibility of this human energy in energy policy and scholarly analyses stands as a reminder of the gendered bias towards public, official and commercial spaces of energy, rather than the productive domestic spaces of households.

So what social and economic changes have recent shifts in Tanzania's energy policy and landscape brought about in Singida? New stuff has arrived in Singida, to be sure, providing new intermediary objects to harness the power of the sun more directly, more efficiently and towards new ends. For some, these technological developments increase connection and output and facilitate consumption. For others, like Nyazakaria and Nyaasha, they extend and accelerate the workday. Even on this electric frontier, capital makes nature work 'harder, faster, and cheaper - indeed preferably for free' (Wark 2015).

But for Nyaturu people in Singida, the cost of a temperate sun - that neither burns too bright nor causes death, dearth or disease - has always required a careful reverence, an investment in the social order through patronage and gerontocracy, 
and responsibility to the landscape. So far, without larger infrastructural projects that create new inclusions and exclusions and that reorder and reconfigure local social and political organization (like solar mini-grids, pay-as-you-go solar systems, or connection to national electricity networks) into bureaucratic abstractions, Singidans continue to acknowledge that their subsistence and development are both emplaced and empeopled - environmental and environment-making. Singida may be a carbon periphery, but, in this way, it is also oikeios topos, a 'favourable place'.

\section{Acknowledgements}

Research for this article was funded by Emory University and by a National Science Foundation grant (Kristin D. Phillips and Erin Dean: grant number 1853185). As always, heartfelt thanks go to Verena Silveri, Zena Saidi, Yusuphu Ramadhani and others in Singida who lent their hospitality, insights and analyses to this research. The Tanzanian Commission for Science and Technology graciously granted research permission, and Enock Makupa at the University of Dodoma lent his support for the project. Melissa Hackman provided invaluable comments on the penultimate draft. Finally, I am greatly indebted to Erin Dean, Omolade Adunbi, Brenda Chalfin, Jamie Cross, Mike Degani and Kristin Doughty for generative conversations and feedback on portions of this manuscript over the course of this rich, three-year, multi-event collaboration.

Kristin D. Phillips is Senior Lecturer in the Department of Anthropology at Emory University in Atlanta, Georgia. Her recent book, An Ethnography of Hunger: Politics, Subsistence, and the Unpredictable Grace of the Sun (Indiana University Press, 2018) was a finalist for the African Studies Association Book Award as well as the African Studies Association of the United Kingdom's Fage and Oliver Prize. Phillips' work has also appeared in African Studies Review, Political and Legal Anthropology Review (PoLAR), Comparative Education Review, Critical Studies in Education and several edited volumes. In 2019, she and Erin Dean were awarded a National Science Foundation senior research grant for their collaborative research on renewable energy and social change in Tanzania. Email: kdphill@emory.edu

\section{Notes}

1. During the course of the twentieth century, occurrences of all three types of events became less frequent, or, in the case of the imaa, ceased almost entirely.

2. Issues of hunger in Singida range from mild deprivation and discomfort to physical debilitation and financial devastation. Approximately twenty to twenty-five of the 169 districts in Tanzania experience such food shortages on an annual basis. The 2010 Demographic and Health Survey estimates stunting in Singida at 39 per cent and wasting at 9 per cent.

3. To ensure confidentiality, names of people and places within the Singida region are pseudonyms. 


\section{References}

ADB. 2015. Renewable Energy in Africa: Tanzania Country Profile. Abidjan, Cote d'Ivoire: African Development Bank Group.

Adunbi, O. 2015. Oil Wealth \& Insurgency in Nigeria. Bloomington: Indiana University Press.

Annecke, W. 2009. 'Still in the Shadows: Women and Gender Relations in the Electricity Sector in South Africa'. In D. McDonald (ed.), Electric Capitalism: Recolonising Africa on the Power Grid. London: Earthscan, 288-320.

Anusas, M. and T. Ingold. 2015. 'The Charge against Electricity'. Cultural Anthropology 30 (4): 540-554. doi:10.14506/ca30.4.03.

Appel, Hannah (2012), 'Offshore Work: Oil, Modularity, and the How of Capitalism in Equatorial Guinea', American Ethnologist, 39 (4), 692-709

Balile, D. 2013. 'Protests over Gas Pipeline in Mtwara Turn Violent, Military Deployed'. Sabahi, 23 May.

Boyer, D. 2015. 'Anthropology Electric'. Cultural Anthropology 30 (4): 531-539. doi:10.14506/ca30.4.02.

Cross, J. 2013. 'The 100th Object: Solar Lighting Technology and Humanitarian Goods'. Journal of Material Culture 18 (4). doi:10.1177/1359183513498959.

Dean, E. 2012. 'The Paradox of Power: Connection, Inequality, and Energy Development on Tumbatu Island, Zanzibar'. Ethnology 49 (3): 185-206. doi:10.2307/41410891.

Degani, M. 2017. 'Modal Reasoning in Dar es Salaam's Power Network'. American Ethnologist 44 (2): 300-314. doi:10.1111/amet.12480.

Economist. 2016. 'Africa Unplugged: Off-Grid Solar Power'. Economist, 29 October.

Fischer-Kowalski, M. 2002. 'Sustainable Development: Socio-economic Metabolism and Colonization of Nature'. International Social Science Journal 50 (158): 573-587. doi:10.1111/1468-2451.00169.

Foster, J. B. 1999. 'Marx’s Theory of the Metabolic Rift: Classical Foundations for Environmental Sociology'. American Journal of Sociology 105 (2): 366-405. doi:10.1086/210315.

Groves, C., K. Henwood, F. Shirani, G. Thomas and N. Pidgeon. 2017. 'Why Mundane Energy Use Matters: Energy Biographies, Attachment, and Identity'. Energy Research \& Social Science 30: 71-81. doi:10.1016/j.erss.2017.06.016.

Gupta, A. 2015. 'An Anthropology of Electricity from the Global South'. Cultural Anthropology 30 (4): 555-568. doi:10.14506/ca30.4.04.

Howe, C. 2014. 'Anthropocenic Ecoauthority: The Winds of Oaxaca'. Anthropological Quarterly 87 (2): 381-404. doi:10.1353/anq.2014.0029.

Iessa, L., Y. A. De Vries, C. E. Swinkels, M. Smits and C. A. A. Butijn. 2017. 'What's Cooking? Unverified Assumptions, Overlooking Local Needs, and Pro-Solution Biases in the Solar Cooking Literature'. Energy Research \& Social Science 28: 98-108. doi:10.1016/j.erss.2017.04.007.

Iliffe, J. 1979. A Modern History of Tanganyika. Cambridge: Cambridge University Press. Jellicoe, M. 1978. The Long Path: A Case Study of Social Change in Wahi, Singida District, Tanzania. Nairobi: East African Publishing House.

Jellicoe, M., P. Puja and J. Sombi. 1967. 'Praising the Sun'. Transition 31: 27-31. doi:10.2307/2934404.

Jensen, C. B. and A. Morita. 2017. 'Introduction: Infrastructures as Ontological Experiments'. Ethnos 82 (4): 615-626. doi:10.17351/ests2015.21. 
Kassenga, G. R. 2008. 'The Status and Constraints of Solar Photovoltaic Energy Development in Tanzania'. Energy Sources: Economics, Planning, and Policy 3 (4): 420-432. doi:10.1080/15567240701421807.

Kawa, N. C., Y. Ding, J. Kingsbury, K. Goldberg, F. Lipschitz and M. Scherer. 2019. 'Night Soil: Origins, Discontinuities, and Opportunities for Bridging the Metabolic Rift. Ethnobiology Letters 10 (1): 40-49. doi:10.14237/ebl.10.1.2019.1351.

Kilyinga, N. and A. Saiboko. 2013. 'Tanzania: State Condemns Mtwara Riots'. Tanzania Daily News, 24 May.

Larkin, B. 2013. 'The Politics and Poetics of Infrastructure'. Annual Review of Anthropology 42: 327-343. doi:10.1146/annurev-anthro-092412-155522.

Latour, B. 1993. We Have Never Been Modern. Cambridge, MA: Harvard University Press.

Latour, B. 2005. Reassembling the Social. Oxford: Oxford University Press.

Makoye, K. 2015. 'As Hydropower Dries Up, Tanzania Moves Toward Fossil Fuels'. Commodities, 29 December.

Matfess, H. 2013. 'Tanzania to Export Electricity While Most of Its Citizens Lack Power'. Foreign Policy in Focus, 7 August.

McKibben, B. 2017. 'The Race to Solar-Power Africa'. New Yorker, 26 June.

Mitchell, T. 2011. Carbon Democracy: Political Power in the Age of Oil. London: Verso.

Moore, J. W. 2015. Capitalism in the Web of Life: Ecology and the Accumulation of Capital. London: Verso.

Moore, J. W. 2017. 'Metabolic Rift or Metabolic Shift? Dialectics, Nature, and the World-Historical Method'. Theory and Society 48: 285-318. doi:10.1007/ s11186-017-9290-6.

National Bureau of Statistics and ICF Macro. 2011. Tanzania: Demographic and Health Survey, 2010. Dar es Salaam: National Bureau of Statistics and ICF Macro.

Olson, H. 2002. Footprints: Memoirs of Howard S. Olson: Howard S. Olson.

Ondraczek, J. 2013. 'The Sun Rises in the East (of Africa): A Comparison of the Development and Status of Solar Energy Markets in Kenya and Tanzania'. Energy Policy 56: 407-417.

Parikh, J. 2000. 'Gender and Health Considerations for Petroleum Product Policy in India'. Energia News 3 (2): 11-13.

Phillips, K. D. 2009. 'Hunger, Healing, and Citizenship in Central Tanzania'. African Studies Review 52 (1). doi:10.1353/arw.0.0135.

Phillips, K. D. 2013. 'Natural Resources in the Making of Nation-Space: Oil, Citizenship, and the New Regionalism in Tanzania. Paper presented at the Meetings of the American Anthropological Association, Chicago, IL.

Phillips, K. D. 2014. 'Gas, Citizenship, and the New Regionalism in Tanzania'. Paper presented at the Meetings of the African Studies Association, Indianapolis, IN.

Phillips, K. D. 2018. An Ethnography of Hunger: Politics, Subsistence, and the Unpredictable Grace of the Sun. Bloomington: Indiana University Press.

Schneider, M. and P. McMichael. 2010. 'Deepening, and Repairing, the Metabolic Rift. The Journal of Peasant Studies 37 (3): 461-484. doi:10.1080/03066150.2010.494371.

Simba, H. 2012. 'Mtwara Residents Oppose Gas Pipeline Construction Plan'. Tanzania Daily News, 28 December.

Simcock, N. and C. Mullen. 2016. 'Energy Demand for Everyday Mobility and Domestic Life: Exploring the Justice Implications'. Energy Research \& Social Science 18: 1-6. doi:10.1016/j.erss.2016.05.019. 
Strauss, S., S. Rupp and T. Loue (eds). 2013. Cultures of Energy: Power, Practices, Technologies. Walnut Creek, CA: Left Coast Press.

URT. 2003. National Energy Policy. Dar es Salaam: Ministry of Energy and Minerals.

URT. 2005. The Rural Energy Act. Dar es Salaam: United Republic of Tanzania.

URT. 2008. The Electricity Act. Dar es Salaam: United Republic of Tanzania.

URT. 2017. Energy Access Situation Report 2016: Tanzania Mainland. Dar es Salaam: United Republic of Tanzania.

Wark, M. 2015. 'The Capitalocene: On Jason Moore’. Public Seminar, 15 October. http:// www.publicseminar.org/2015/10/the-capitalocene/

Watts, M. 2005. 'Righteous Oil? Human Rights, the Oil Complex, and Corporate Social Responsibility'. Annual Review of Environment and Resources 30: 373-407. doi:10.1146/annurev.energy.30.050504.144456.

Williams, R. 1980. Problems in Materialism and Culture. London: Verso.

Winther, T. and H. Wilhite. 2015. 'Tentacles of Modernity: Why Electricity Needs Anthropology'. Cultural Anthropology 30 (4): 569-577. doi:10.14506/ca30.4.05.

Wogan, D. 2013. 'Africa's Energy Poverty, as Seen from Space'. Scientific American, 28 June. 